\title{
Forum
}

\section{Why I Wrote Clarke's Latin}

\section{Ed Clarke}

Head of Classics, Highfield School, UK
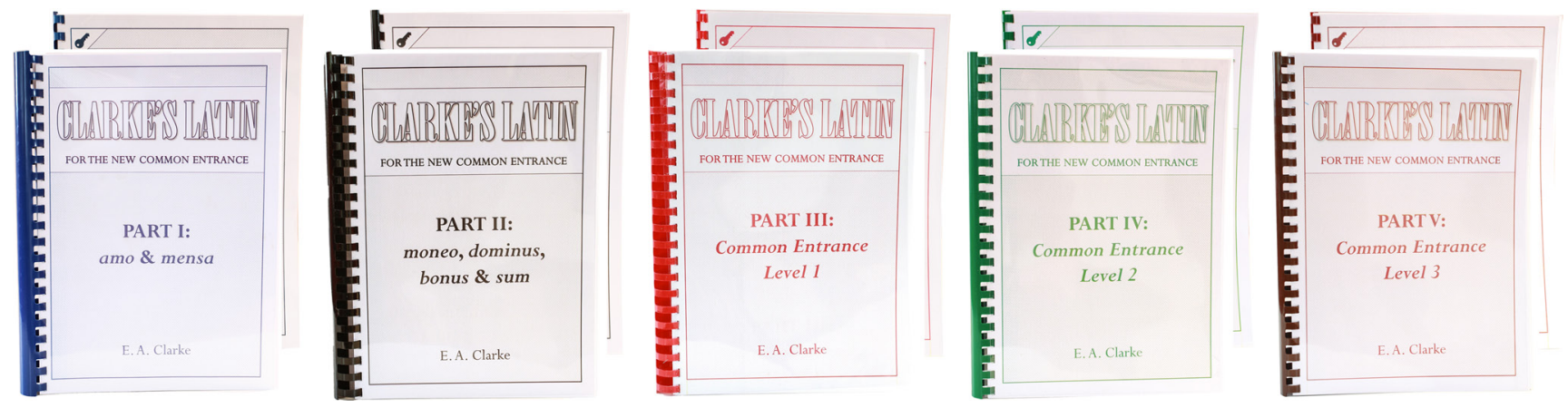

Figure 1. Clarke's Latin: Complete Course

Never has the phrase annus horribilis seemed more applicable than in this past dreadful year. Virgil's lacrimae rerum have, I imagine, been with us all throughout; though I doubt that it was 'the tiers of things' he had in mind.

Though very few silver linings have presented themselves beneath the black cloud of the coronapocalypse, I have endeavoured to use such extra time as it has afforded in the furtherance of my Clarke's Latin project. Happily I was at last able in November to publish all 11 volumes - five parts, their corresponding answer keys and a batch of practice papers in the new Common Entrance format. (Part V completes CE Level 3. Depending how long the current lockdown persists, I may well be some way towards finishing the final two parts - for Common Academic Scholarship and Eton scholarship/GCSE/AS - later in the year.)

I began work on the project in the summer of 2019. I had by then realised just how much practice a pupil needs before genuinely mastering any given area of the language. Too often, a class I believed to have fully grasped an element of grammar would, a few topics later, appear to have forgotten that element in its entirety. I wanted to create a series of books whose exercises were so numerous as to bring that mastery inevitably about, while rescuing teachers from the burden of writing endless materials themselves.

This I was able to do only with the assistance of modern technology. I developed a method of producing Latin words and simple phrases, as well as their English translations, through computer generation. The computer then arranges these in a random order, creating exercises which are not only copious but in fact contain every possible permutation of the available vocabulary and grammar.

Thus while my first Latin course, Variatio, provided 60 questions on the present tense of first conjugation verbs, Clarke's Latin

Author of correspondence: Ed Clarke, E-mail: eaclarke@gmail.com

Cite this article: Clarke E, (2021). Why I Wrote Clarke's Latin. The Journal of Classics Teaching 22, 71-75. https://doi.org/10.1017/S205863102100012X gives 960. Over the remainder of Part I, there are 1000 questions on the nominative case of mensa, another 1000 on the accusative and more than 3000 on the remaining cases, prepositions, interrogatives and imperatives. Some are individual words and phrases for analysis and translation; others are grammatical, or etymological; others still, complete sentences from Latin to English and vice versa.

The entire course spans more than 2200 pages and a 250000 words, including 20000 questions and 30000 words of continuous Latin prose. As such, it is one of the most extensive sets of rudimentary Latin resources ever created.

I also wanted to approach the language in a way which compelled the student to be analytical, with a close eye for detail, from the very start. More than anything else, my guiding principle through the past ten years of teaching has been that I always want my pupils to understand why something means what it means, not merely to be able to hazard a translation.

To this end, I altered somewhat the order in which I introduced the very basics. Every traditional course I have encountered has always followed the same pattern: amo; negatives and conjunctions; the nominative case of mensa and finally the accusative case. After these introductory exercises comes the first unseen which, not unreasonably, contains adverbs and subordinate clauses in order to make the passage flow and function as a story.

Unfortunately, it has been my experience that expecting pupils to handle these further complexities intuitively has often met with significant confusion. Clarke's Latin, therefore, teaches adverbs and then subordination as discrete topics after the nominative. At this stage, a system of analysis is put into place. The subject is underlined; verbs put in a box. Adverbs are bracketed, while sub-clauses are split off with slashes.

The first unseen translation follows, without the added complication of the accusative case. Admittedly, producing Latin prose 



Figure 2. Sample Comprehension, Translation and Grammar Questions

\section{Exercise 49 - THE TREACHERY OF TARPEIA, PART I}

Not long after the founding of Rome - many centuries before the empire and its annexation of Britain the Romans are at war with a neighbouring tribe called the Sabines. Here Tarpeia, daughter of the Roman commander Spurius Tarpeius, attempts to betray Rome to Titus Tatius, king of the Sabines, in return for jewellery.

Titus Tatius et advenae Romam oppugnant.

incolae Romam conservant. copiae, quod patriam magnopere amant, fortiter pugnant.

Spurius Tarpeius copias bene gubernat.

filia tamen, Tarpeia nomine, patriam non amat. Tarpeia pecuniam et divitias amat. divitias

5 magnopere amat.

olim Titus Tatius stat et advenas spectat. Tarpeia et appropinquat et salutat. Titus Tatius

Tarpeiam etiam salutat. statim puella iuvat. postquam portas demonstrat, Tarpeia et

advenae Romam intrant. advenae et incolae diu pugnant.

Tarpeia advenas sic iuvat. Titus Tatius tamen divitias non dat, quod Tarpeiam non amat.

10 Tarpeiam non amat quod puella patriam vulnerat. Titus Tatius copias vocat. copiae appropinquant; deinde galeas et hastas iactant. Tarpeiam necant.

$\begin{aligned} \text { advena } & - \text { invader, foreigner } \\ \text { Roma } & - \text { Rome } \\ \text { conservo } & - \text { I protect } \\ \text { guberno } & - \text { Iguide } \\ \text { divitiae } & - \text { riches } \\ \text { porta } & - \text { gate }\end{aligned}$

$\begin{aligned} \text { iuvo } & - \text { I help } \\ \text { demonstro } & - \text { I point out } \\ \text { vulnero } & - \text { (here) I damage } \\ \text { galea } & - \text { helmet } \\ \text { iacto } & - \text { I throw }\end{aligned}$

Figure 3. Sample Translation 


\section{Chapter 6: Prepositions Governing the Accusative}

A preposition shows the link between two elements in a sentence.

The slave-girl is walking ... the goddess.

In this example, a word is required to show the link between the slave-girl walking and the goddess. We can think of a number of possibilities.

$$
\text { The slave-girl is walling }\left\{\begin{array}{c}
\text { towards } \\
\text { away from } \\
\text { with }
\end{array}\right] \text { the goddess. }
$$

Here are some Latin prepositions.

\begin{tabular}{cc}
\multicolumn{2}{c}{ Vocabulary $M$} \\
ad & to, towards \\
ante & before, in front of \\
circum & around \\
contra & against \\
in & into, onto \\
inter & among, between \\
per & through \\
post & after, behind \\
prope & near \\
propter & because of, on account of \\
super & orer, abore \\
trans & across
\end{tabular}

In Latin, prepositions have to be followed by a particular case. They are said to govern that case.

Most Latin prepositions govern the accusative, including all those included in the vocabulary list above.

This means that whatever word comes after a preposition must go into the accusative case.

Towards the queen. ad reginam.

Across the water.

trans aquam.
Through the waves.

$$
\text { per undas. }
$$

\section{Exercise 5 I}

Translate the following prepositional phrases into English.

1. ad poetas.
2. ad filias.
3. propter hastas. with only nominatives is a little excruciating, but the benefits to the students' understanding as a result of this simple practice have been immense.

Here is the opening paragraph of that first unseen (entitled 'A Winged Intruder'), along with its analysis. (Words in bold are glossed.) (olim) schola laborat. grammatista imperat. iuvat [et] nuntiat, / [dum] puellae laborant/. puellae (bene) laborant, / [quod] grammatista spectat/. / [si] puellae (diu) laborant/, grammatista laudat. (subito) intrat vespa. vespa (celeriter) volat et (magnopere) bombitat. (mox) puellae turbant. / [ubi] vespa appropinquat/, puellae [et] clamant [et] reformidant. 


\section{Exercise 149 - 'Allo 'Allo!}

The classic 1980s sitcom 'Allo! 'Allo! tells the farcical story of René Artois, a café-owner in WWII France. $\mathrm{He}$ is hiding two British airmen for the French resistance. He is also keeping a painting by Van Klomp known as 'The Fallen Madonna with the Big Boobies' in his cellar for the Germans to sell after the war (a painting which Hitler wishes to acquire for himself via Herr Flick of the Gestapo). On top of this, René must aroid his wife discovering that he is having affairs with both of the waitresses in the café.

Renatus in Gallia habitat, ubi tabernam habet. Renatus amicique magno in periculo saepe sunt. quamquam cotidie multi Germani tabernam intrant et vinum potant, Renatus duos incolas Britanniae pro perfugis celat.

feminam, nomine Edetam, quoque habet. Edetam non amat. ambas tamen ancillas magnopere amat; Edeta ignorat. si femina Renatum cum una ex ancillis videt, verba irata clamat: 'o Renate, cur ancillam in brachiis tuis tenes?' sic semper respondet: 'tu femina stulta!' deinde 'ancillae,' explicat 'quod misera forte erat, solacium dabam' aut aliqua se excusat. Edeta, quod credula est, maritum magnopere laudat. 'o Renate,' inquit, 'quam benignus es!'

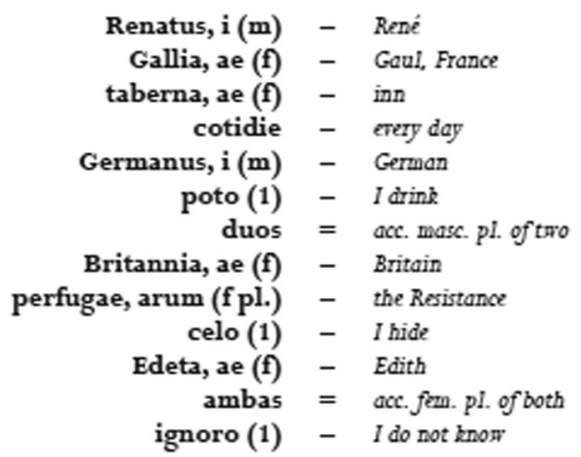

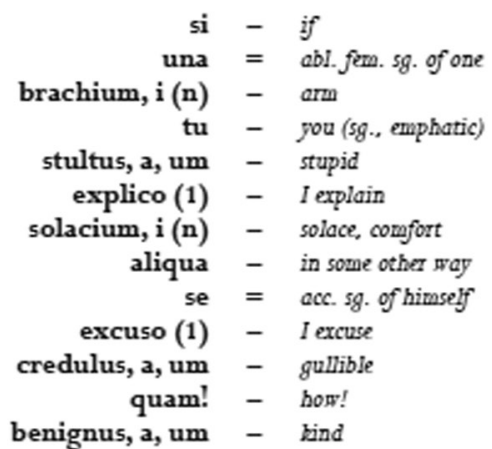

Figure 5. Sample Translation

Once pupils have the hang of subordination and can cope with continuous prose - and, indeed, their first Latin composition, which follows the exercise above - they move on to the accusative case. The system of analysis grows with each chapter to encompass other cases and parts of speech.

The passages themselves are, I hope, entertaining and of historical interest. Some, particularly at the outset, are confected creations of my own; others I adapted from Livy, Tacitus, Pliny and a variety of other authors. Greek mythology features heavily, as well as Roman history. A few anachronisms pop up from time to time Hercule Poirot, 'Allo 'Allo! and Nigel Farage, among others.

Conscious of teachers' ever-increasing workload, I have endeavoured to make the books as useful as possible. As well as the quan- tity of resources, they are in workbook format, eliminating the need for files or exercise books. The answer keys allow pupils to mark the majority of their own work, while teachers need only see to significant exercises such as unseens, comprehensions and grammatical questions based on passages. Differentiation too is built into the course, with simple materials which are appropriate for the weakest as well as tough English to Latin sentences and prose composition for the most able.

It has been a colossal undertaking to produce but I am delighted to have emerged the other end with a set of resources which, so far, have done a great deal for my own pupils. I very much hope that Clarke's Latin will continue to gain traction in the coming years and provide similar assistance to colleagues elsewhere. 


\section{Chapter 9: The Indirect Statement}

\section{The Present Passive Infinitive}

All the infinitives we have seen so far have been present active infinitives.

In fact, Latin has a number of infinitives, in various tences and voices.

The present passive infinitive is formed by altering the final 'e' of the present active infinitive to an ' $\mathrm{i}$ ' - aneri, moneri and ardiri. The $3^{\text {ad }}$ and $3{ }^{3 /{ }^{\Delta}}$ conjugatione replace the entire ending - rogi and capi.

\begin{tabular}{|c|c|c|c|c|}
\hline Conj. & \multicolumn{2}{|c|}{ ACtive } & \multicolumn{2}{|c|}{ Passive } \\
\hline$\left.\right|^{\text {st }}$ & mare & to lore & $\operatorname{mari}$ & to be lored \\
\hline $2^{\text {nd }}$ & monere & to marn & moneri & to be marnod \\
\hline $3^{\text {rd }}$ & regere & to rule & regi & to be ruled \\
\hline $4^{\text {th }}$ & sudire & to heur & audiri & to be heard \\
\hline $31 / 2^{\text {th }}$ & capere & to tabe & cypi & to be taken \\
\hline
\end{tabular}

captivi miseri servari magoopere cupiebant.

The miserable captires deperately nented to be saved.

dux iuseit incoles occidi.

The general ordered that the notive be killed.

\section{The Indirect Statement}

We hrve often seen direct speech - in inverted commse - in stories throughout these booke.

$$
\begin{aligned}
& \text { reginz 'copiae' inquit 'celeriter appropinquant.' } \\
& \text { Troops are approoching quichly, soid the queen. }
\end{aligned}
$$

Indirect speech does not have inverted commas.

It is reported speech, introduced by 'that'.

The quarn seid that the troops nere opproaching quickly.

Latin does not have 2 word for 'that' in this context. Inetead, a special construction called the indirect statement is used.

This is made up of an accusative and an infinitive.

regina dixit copias celeriter appropinquare.

(lit. The quasen esid the troops to be approoching quiclly.)

Figure 6. Sample Grammar Explanation 